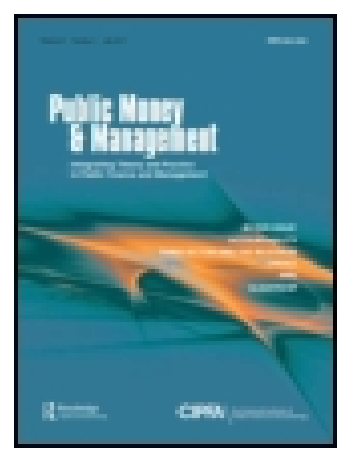

Public Money \& Management

\title{
Implementing a divergent response? The UK approach to bribery in international and domestic contexts
}

\section{Nicholas Lord, Alan Doig, Michael Levi, Karin van Wingerde \& Katie Benson}

To cite this article: Nicholas Lord, Alan Doig, Michael Levi, Karin van Wingerde \& Katie Benson (2020): Implementing a divergent response? The UK approach to bribery in international and domestic contexts, Public Money \& Management, DOI: 10.1080/09540962.2020.1714212

To link to this article: https://doi.org/10.1080/09540962.2020.1714212

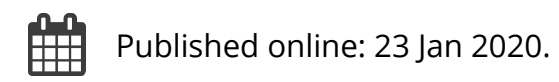

Submit your article to this journal ๔

Џ Article views: 28

Q View related articles $\square$

View Crossmark data ¿ 


\title{
Implementing a divergent response? The UK approach to bribery in international and domestic contexts
}

\author{
Nicholas Lord ${ }^{\mathrm{a}}$, Alan Doig ${ }^{\mathrm{b}}$, Michael Levi ${ }^{\mathrm{c}}$, Karin van Wingerde ${ }^{\mathrm{d}}$ and Katie Benson ${ }^{\mathrm{e}}$ \\ ${ }^{\mathrm{a}}$ University of Manchester, UK; ${ }^{\mathrm{b}}$ Durham University, UK; ${ }^{\mathrm{c}}$ Cardiff University, UK; ${ }^{\mathrm{d}}$ Erasmus University Rotterdam, The Netherlands; ${ }^{\mathrm{e}}$ Lancaster \\ University, UK
}

\section{ABSTRACT}

This paper analyses UK domestic bribery. The authors argue that in both domestic and international contexts, cases are not numerically significant but that changes in how the UK government approaches bribery in the international context means that, where once domestic bribery was addressed more rigorously than bribery in the international context, this imbalance may be being steadily reversed. The paper concludes by setting out the implications that this identifiable divergence may have for the effective policing of bribery in the domestic context. The paper makes an empirical and theoretical contribution to the literature on corruption in the UK.

\section{IMPACT}

This paper analyses the UK response to bribery and corruption and provides evidence of a divergent approach, in terms of strategy, policy and enforcement action, to addressing bribery in the domestic and international contexts. This has adverse implications for the prevention, detection, and investigation of bribery. In order to reduce the divergence and reinforce the domestic focus, governments need to ensure better and more detailed data for monitoring of the extent of bribery, the presence of a single lead for the domestic context to ensure consistency and co-ordination, and the availability of training for relevant staff to make certain relevant stakeholders are alert to emerging corruption issues. The empirically informed insights and arguments in this paper are relevant to policy-makers and practitioners working in the area of anti-corruption, as well as non-governmental organizations seeking to scrutinize anti-corruption strategies, policies and practice in the UK.

\section{KEYWORDS}

Anti-bribery institutions; bribery; criminal prosecution; law enforcement; UK Bribery Act (UKBA)

\section{Introduction and context}

Historically in the UK, there has been a divergence in the attitudes and responses of governments towards domestic and international bribery by UK persons (including corporations). Domestic bribery, particularly of political and public sector personnel, was increasingly presented as being less acceptable within a growing expectation of high public standards and the public interest (Doig, 1984). The Acts passed in 1889, 1906 and 1916 provided the legal framework for behaviours, relations and acts being labelled as 'corrupt' in the context of the domestic (local and central) duties of public officials with public inquiries (such as those relating to the Poulson and other corruption scandals in the early 1970s) demanding not only effective anti-bribery legislation but also related legislation (for example, conflict of financial interests in local government). The UK Bribery Act (UKBA) 2010 consolidated and updated the existing legislation.

Apart from the limited domestic jurisdictional reach of the longstanding pre-UKBA legislation (though the Anti-terrorism, Crime and Security Act 2001 gave them extra-territorial jurisdiction), much of the lack of interest in bribery overseas arose from perceptions among government departments on what was or was not acceptable abroad in terms of the primacy of UK economic/political interests (see Doig, 2011), particularly involving countries where corruption was prevalent or a pragmatic necessity in a highlycompetitive export environment (see Gutterman, 2017).

Neither the 2001 extension of the jurisdiction of existing legislation, nor being a signatory to the OECD Convention on Combating Bribery of Foreign Public Officials in International Business Transactions, were enough to address the concerns of OECD's Working Group on the Convention about the adequacy of the UK's response to bribery in the international context. Indeed, the inadequacy of the legislative framework, including the inadequacy of corporate criminal liability alongside this in terms of, for example, the restrictive nature of identification principle (Lord, 2014), for both the domestic and the international context had long been a concern of a range of bodies, from 1976 Royal Commission on Standards of Conduct in Public Life to the UK's ratification of UNCAC in 2006. This was publicly accepted by UK governments and led $(a)$ to the UKBA and a number of policy and strategy documents; and 
(b) in order to implement the intent of the UKBA for the international context, a clearly-defined set of institutional changes and resourcing arrangements within a very public statement of commitment through a 'landmark' [sic] international anti-corruption summit in London in 2016.

\section{The research context and methodology}

The absence of similar changes and arrangements for effective implementation of the UKBA for the domestic context is reflected in the 2018 City of London Police's statement that, while it has lead responsibility for fraud within the UK, there is no lead responsibility for bribery within the UK and, even if there was, there would be 'a need for infrastructure, investment and resourcing' to ensure an effective law enforcement response (House of Lords Bribery Act Committee, 2018, p. 15). This suggests a change to the historical divergence in terms of priorities for the domestic and international contexts, and a major research gap in terms of the contemporary nature and control of domestic bribery. This paper contributes to the current discourse on bribery in the UK by asking if there is a divergence in enforcement of domestic and international bribery by the UK through four research questions:

- Does the contemporary response to domestic and international bribery diverge?

- What do we know about the nature, extent and scope of domestic bribery in the UK?

- If the contemporary responses to domestic and international bribery diverge, are there identifiable reasons for this?

- What are the implications for future approaches to bribery in the domestic context?

The research was undertaken between October 2016 and September 2018 with funding from the British Academy/Leverhulme Small Research Grants 2016 round. The research involved both intensive and extensive research approaches and the implementation of mixed methods over three phases to triangulate and corroborate the findings:

- A systematic search of the literature to identify relevant academic and 'grey' scholarship on bribery and corruption, as well as a desk review of official reports and publications (see Saunders, Lewis, \& Thornhill, 2009).

- A Freedom of Information (FOI) request to all police forces in the UK plus specialist anti-corruption enforcement authorities such as the Serious Fraud Office (SFO), the Ministry of Defence Police and the City of London Police ( $N=45$; all replied) to establish the number, type and outcome of cases recorded for investigation in relation to the bribery of public and/or private sector personnel under the 1889, 1906, 1916 and 2010 Acts.

- Semi-structured interviews with six informed experts in the areas of anti-bribery and corruption, including senior prosecutors, and senior bribery trainers and investigators, to gain insight into the nature of domestic bribery and issues relating to the regulation and control of these behaviours.

\section{Is there a divergence? Legal framework, government attention, institutional change, and the research issue}

\section{Legal context}

Bribery is a transactional crime-it consists of an illicit exchange involving the transfer of a benefit to the recipient(s), directly or indirectly, immediately and over a longer term, which may comprise both monetary payments and other types of inducements, to facilitate the circumventing of legally prescribed rules and procedures, and usually consists of the abuse or misuse of otherwise 'normal' relationships (Doig, 2006, p. 116), to the advantage of the provider directly or on behalf of another party. Note that the terms 'corruption' and 'bribery' are often used interchangeably. Corruption is essentially about the 'corruption' of public office or its use for private, personal or partisan interests. This may take a number of criminalized forms, such as embezzlement or bribery, or ethical issues, such as conflict of interest or nepotism; this paper focuses on bribery, as defined by the UKBA. In legal terms, common law offences of bribery and embracery (bribery of a juror) in England and Wales, and bribery and accepting a bribe in Scotland, have existed for centuries, with focus placed on the corruption of those in 'public office' (whose definition invariably relied on case law interpretation).

This was reinforced in statute: the Public Bodies Corrupt Practices Act 1889 sought to criminalize local government officials acting 'corruptly' in connection to their public body. The Prevention of Corruption Act 1906 brought into scope the private sector (agents acting corruptly in relation to a principal's business) and central government officials. The Prevention of Corruption Act 1916 introduced a presumption of corruption component, shifting the burden of proof to public sector defendants to prove that their behaviours were not corrupt in offences involving public sector contracts under the 1889 and 1906 Acts where it had already been proved that a bribe had been given or received. In 2002, the AntiTerrorism, Crime and Security Act 2001 came into force and introduced an overseas element to ensure that bribery and corruption, as legislated for in the 
Prevention of Corruption Acts, committed by UK persons in other jurisdictions was also punishable in the UK.

This latter amendment was an attempt to satisfy the requirements of the OECD's 1997 Anti-Bribery Convention. However, the OECD's monitoring process considered the changes in the 2001 Act to be insufficient and recommended 'that the UK proceed at the earliest opportunity to enact a comprehensive anti-corruption statute' (OECD, 2003, p. 17). The outcome was the UKBA, which consolidated all bribery offences, accounting for domestic and foreign bribery by natural and legal persons, and including four specific offences relating to giving or offering a bribe, receiving or soliciting a bribe, bribing a foreign public official, and a failure of commercial organizations to prevent bribery. The UKBA refers to bribery as the offering, promising or giving (active bribery), or the requesting, agreeing to receive or accepting (passive bribery) of a financial or other advantage with the intention to induce improper performance in relation to a relevant function or activity (such as a public function or in the course of employment).

\section{Government attention}

In line with this developing legal framework, corruption and bribery were identified as a high-priority public policy concern by the UK government (see HM Government, 2014). They also remain high on the agenda of other sovereign states and intergovernmental bodies such as the UNODC, the Working Group on the OECD Convention and the European Union (see European Commission, 2014). The 2016 Anti-Corruption Summit convened by the UK government spelt out the rhetoric of the UK's commitment in terms of the international context, and the UK government also stated that corruption is a threat to the UK's 'national security and prosperity, both at home and overseas' (HM Government, 2017, p. 7). The then Home Secretary Amber Rudd asserted that 'although the UK enjoys higher levels of integrity than many other countries, we are not immune from the effects of corruption. Stories of corruption can undermine confidence in the institutions and the business reputation more widely' (HM Government, 2017, p. 7, 5).

The UK government has taken an active role in developing a policy framework to address bribery. The 2014 Anti-Corruption Plan, which has both domestic and international perspectives, outlined the government's intention to build a better picture of the threat from corruption and the ways in which the UK is vulnerable by increasing protection against the organized criminals who corrupt public sector officials; strengthening integrity in key sectors and institutions; and strengthening the UK's law enforcement response to more effectively pursue those who engage in corruption or launder their corrupt funds in the UK. Most recently, the UK AntiCorruption Strategy 2017-2022 was published focusing on six priorities: reducing the insider threat in high-risk domestic sectors such as borders and ports; reducing corruption in public procurement and grants; promoting integrity across the public and private sectors; strengthening the integrity of the UK as an international financial centre; improving the business environment globally; and working with other countries to combat corruption.

\section{Institutional change}

In addition to the policy framework and a very public commitment to addressing corruption underlined by the Anti-Corruption Summit in 2016, where several commitments were made by the UK government as part of a drive to 'galvanize a global response to tackle corruption', the government also introduced institutional reforms. Most of these, however, were focused on or prioritized international bribery.

On the enactment of the UKBA, the SFO was designated with lead responsibility for international cases, to whom Foreign and Commonwealth Office (FCO) staff were advised to report allegations (FCO, 2011; see also OECD, 2017, p. 104). In the same year, an All-Party Parliamentary Group on Anti-Corruption was established to bring together interested members of the House of Commons and House of Lords to raise awareness of the impact of international corruption and to enhance and strengthen UK anti-corruption policies and mechanisms. In 2014, the government established a post of Anti-Corruption Champion. In 2015, an Inter-Ministerial Group on Anti-Corruption was created and the City of London Police Overseas Anti-corruption Unit, along with the Metropolitan Police's International Proceeds of Corruption Unit, were transferred to the National Crime Agency's (NCA's) Economic Crime Command to become the International Corruption Unit (ICU), funded largely by the Department for International Development (DFID) and with some 50 staff focusing on bribery, money laundering and financial sanctions evasion (see Harvey, this issue). An integrated approach to restitution of illicit funds held in the UK was drafted and agreed by a number of agencies (see Campbell \& Lord, 2018).

In July 2017, the International Anti-Corruption Coordination Centre (IACCC), hosted within the NCA, was launched to bring together specialist law enforcement officers from multiple agencies around the world to tackle allegations of high-level corruption where co-ordination and cooperation was crucial. In December 2017, the UK government announced the creation of the National Economic Crime Centre 
(NECC) - also hosted within the NCA -in order to plan, task and co-ordinate operational responses across agencies bringing together the UK's capabilities to tackle economic crime more effectively, with particular focus on bribery and corruption. It also established a memorandum of understanding in 2017, entitled 'Tackling Foreign Bribery', signed between various law enforcement bodies, including the SFO, the City of London Police, the Crown Prosecution Service (CPS), the Scottish government's Crown Office and Procurator Fiscal Service, the Financial Conduct Authority, the Ministry of Defence Police, the NCA and HM Revenue and Customs. Further legislative reformsuch as 'unexplained wealth orders' (UWO) under the Criminal Finances Act 2017-has underlined the continuing emphasis on the international context (even though such orders were addressed domestically through applications to the UK High Court).

\section{Developing the research issue: reviewing the domestic context}

The UK continues to be rated an 'active enforcer' (Transparency International, 2018) of the OECD AntiBribery Convention in the international context based on the number of investigations commenced and sanctions brought in relation to its share of world exports (only six other countries are considered 'active'). Yet, in contrast to the developments outlined above, it was being argued that bribery within the UK has not been given the same level of attention and support as it has in the international context, despite both domestic and external criticisms of this: an early UNCAC review noted that 'there is no typology of corruption available, or any analysis and evaluation of the situation in the UK... nor is there any specialised agency which is responsible for a centralized co-ordination of nation-wide anticorruption work' (UNODC, 2011, p. 7; see also Transparency International, 2011).

A few years later, in 2018, evidence to a House of Lords inquiry into the UKBA from a senior officer from the City of London Police noted that 'domestically, the picture has not been articulated particularly well. The spotlight has not been on what happens within the United Kingdom and the response to it. One might say that that allows the growth of corrupt activity, as we are not really focusing on those aspects' (House of Lords Bribery Act Committee, 2018, q108). In the same year, GRECO noted that, in relation to what it terms 'persons who are entrusted with top executive functions', it 'did not come across a co-ordinated system for analysing major corruption risk factors ... in an unconditional strategic manner at central governmental level' (GRECO, 2018, p. 13).

The paper argues that, while the legislative framework and the publication of policy documents suggest a common approach by governments, that approach diverges in terms of institutional changes and resourcing arrangements. Thus the question underpinning our research was why there appears to be a lack of implementation focus on bribery in the domestic context?

\section{What do we know about the nature, extent and scope of domestic bribery in the UK?}

\section{The scale of domestic bribery}

In the second phase of the research, the FOI data showed the actual number of recorded cases of domestic bribery in the UK. Table 1 presents the absolute number of bribery offences recorded by UK police forces from 1989 onward and differentiated by the legislation used. The recording periods of the different forces varied quite significantly-some forces' records went back to 1989, while others only recorded one year, making direct comparison of the pre- and post-Bribery Act periods impossible. Forty two out of the 47 forces and authorities surveyed provided detail as to whether the offences were recorded under the Bribery Act 2010 or earlier legislation. However, in five responses, the specific legislation was not noted, though the year of recording was provided (except for one force) and in these cases we inferred that those recorded in 2011 onwards would have been recorded under the UKBA.

For research data, this means that one case included in the 202 pre-UKBA legislation cases may have been a UKBA offence, and that 58 of the cases included in the 125 post-UKBA figure may have been offences relating to earlier legislation: this may be due to the time delay between offence and detection, and the inability to make UKBA charges retrospective. However, the figure of 58 includes 41 cases recorded by Police Scotland, all of which were recorded between 2013 and 2016. According to Police Scotland, 'crimes in Scotland are recorded in accordance with the Scottish Government Justice Department crime classification codes and are not thereafter subcategorised' (FOI response). It is therefore possible that some of these 41 cases were pre-UKBA offences, though we cannot estimate how many.

Based on responses to the FOI requests, 327 bribery offences were recorded between 1989 and 2017, including 125 since the UKBA came into force in 2011. If we break down the data further, authorities with national jurisdiction, such as the Ministry of

Table 1. Recorded bribery data (1989-2017).

\begin{tabular}{lc}
\hline Legal framework (dates) & Number of recorded cases \\
\hline Prevention of Corruption Acts (1989-2011) & 202 \\
UKBA (2011-2017) & 125 \\
Total & 327 \\
\hline
\end{tabular}


Defence Police (63 cases between 1999 and 2016) and the SFO (43 cases between 2012 and 2016), recorded the highest number of cases. In terms of police forces, Thames Valley Police, (44), Police Scotland (41), West Mercia Police (22), the Police Service of Northern Ireland (15), Warwickshire Police (12) and Greater Manchester Police (12) recorded the highest numbers. For the time period 2011-2017 (which may not entirely be cases investigated under the UKBA), a total of 125 cases was recorded, with the greatest numbers recorded by Police Scotland (41), Thames Valley Police (15) and Greater Manchester Police (11).

Given the problematic variation in time periods for which responses were received, and to provide a better reflection of recorded cases over time, we calculated the rate of recording per year for each force. From this analysis, it can be seen that the Ministry of Defence Police and SFO recorded a high number of total cases, with 3.5 and 8.6 cases per year. In terms of constabulary police forces, Police Scotland (10.2), Thames Valley Police (4.8) and West Mercia Police (2.2) have the highest rate of recording per year. For the period 2011-2017, the analysis indicates that the forces with the highest rate of recording of UKBA offences were Police Scotland (7.5), Thames Valley Police (2.7) and Greater Manchester Police (2). The current research thus suggests that while a significant minority of UK police forces have had no recorded domestic cases under the UKBA, some 25 police forces plus the Ministry of Defence Police and the SFO have had a total of 125 cases over a 6-year period (or $\approx 21$ a year).

The research data were triangulated against the annual average of cases with two further sets of data. The first was provided by the Home Office on cases brought under the 1889 and 1906 Acts (the 1916 Act increased the maximum penalty under these Acts for certain offences) between 1965 and 1978-see Table 2.

These data suggest that the annual average number of cases brought under the 1889 Act was less than three, while the number brought under the 1906 Act was over 30; conspiracy to commit corruption cases were less than four per year. The other set of data was provided by the Office for National Statistics (ONS) in 2018 when it published for the first time data on corruption related offences recorded by the police. These 'experimental statistics' include all four UKBA offences, plus the offence of misconduct in public office-see Table 3.

Table 2. Bribery offences from 1965 to 1978 (Doig, 1984).

\begin{tabular}{lccc}
\hline & \multicolumn{3}{c}{ Crown Court } \\
\cline { 2 - 4 } Charges & Cases & Annual average & Convicted \\
\hline 1889 Act; s1(1) & 43 & $>2.9$ & 32 \\
1889 Act; s1(2) & 24 & $>1.6$ & 23 \\
1906 Act s1 & 483 & $>32.0$ & 350 \\
Conspiracy to commit corruption & 52 & $>3.4$ & 45 \\
\hline
\end{tabular}

Table 3. ONS corruption data (ONS, 2018).

\begin{tabular}{lccc}
\hline Offences/dates & $\begin{array}{c}\text { July 2016- } \\
\text { June 2017 }\end{array}$ & $\begin{array}{c}\text { July 2017- } \\
\text { June 2018 }\end{array}$ & Total \\
\hline $\begin{array}{l}\text { Offences relating to offering, } \\
\text { promising or giving bribes (s.1 and } \\
\text { s.6 UKBA) }\end{array}$ & 13 & 9 & 22 \\
$\begin{array}{l}\text { Offences relating to requesting, } \\
\text { agreeing to receive and accepting } \\
\text { bribes (s.2 UKBA) }\end{array}$ & 4 & 6 & 10 \\
$\begin{array}{l}\text { Commercial organization-failure to } \\
\text { prevent associate bribing another } \\
\text { with intent to obtain or retain } \\
\text { business or advantage (s.7 UKBA) }\end{array}$ & 0 & 1 & 1 \\
\begin{tabular}{l} 
Misconduct in a public office \\
\hline
\end{tabular} & 62 & 106 & 168 \\
\hline
\end{tabular}

As the ONS indicates, other than for unlawful deaths, police recorded crime data are not designated as national statistics. Furthermore, data collected prior to April 2018 are not comparable with data after April 2018, as improvements in data collection procedures mean that for the period April to June 2018, data were only available from 38 of the 43 police forces in England and Wales. In terms of bribery specifically, the absolute numbers of recorded offences here are low relative to the FOl data but it is very difficult to make comparisons between the two years of corruption data published by the ONS (currently classed as Experimental) and the FOI data, because they relate to different numbers of police forces and varying time periods of available recorded data across forces. Most offences in the ONS data relate to the broader construct of 'misconduct in public office' which can range from the exploitation of an official position to facilitate a personal or sexual relationship, or acting while under a conflict of interest in a prejudicial manner (see Law Commission, 2016), raising questions over how many may involve bribery.

Nevertheless, when comparing the current data with the data in Tables 2 and 3, the number of recorded cases shows no significant increase or decrease since 1965. If a small number of significant variations often occasioned by a single case with multiple offences and offenders are taken into account, then the number per force is about two to three recorded cases a year. There are other means at the disposal of police forces, including decisions taken by local police forces to investigate under the Fraud Act 2006 (for example fraud by abuse of position) cases where bribery allegedly occurred, and by the CPS to prosecute accordingly; the use of money laundering provisions in the Proceeds of Crime Act (POCA); the use of the 1889 Act for offences committed prior to the coming into force of the UKBA; and-for the moment-the common law offence of misconduct in public office. Within the limits of the research and the current state of recorded bribery data-which continues to be a function of what is chosen to report, record, and investigate, and by whom-the paper has demonstrated that there continue to be few bribery 
cases and that there is little evidence from which it may reasonably be concluded whether or not the UKBA has had an impact on levels of domestic cases investigated or prosecuted.

\section{The nature and scope of domestic bribery}

The FOI data provided qualitative insights into the nature of the cases, as descriptions were provided by forces as to whether the bribery was public or private, domestic or international, and the outcome of the case. However, the information was very inconsistent, with some forces providing elaborate accounts of the bribery offences, some providing brief and unspecific accounts, for example 'corruption (public sector)'; some providing no description at all other than stating the offence (for example a section 1 UKBA violation, or 'giving bribe'); and, finally, some providing nothing beyond the number of cases and year recorded. Most cases were recorded under section 1 of the UKBA (offering, promising or giving a bribe), section 1 of POCA (primarily in SFO cases, but in other forces also) and section 1 of the Public Bodies Corrupt Practices Act 1889. From the data collated, many of those involved had a modest socioeconomic status. The range of actors implicated in the FOI responses and (where available) an indication of the purpose of the bribe shows low-level appointments (such as driving test inspectors, hotel workers and planning officers) and routine offences (insider information, award contracts etc.); there was no data in the FOI responses about the financial value of the bribes. However, in other research analysing domestic and international bribery in England and Wales, domestic bribes tend to be 'cheaper' than foreign ones (Andresen \& Button, 2018, p. 9). More specifically, $95 \%$ of convictions involving bribes under $£ 100,000$ were domestic (and 5\% were overseas), whereas only $40 \%$ of convictions involving bribes over $£ 100,000$ were domestic, with $60 \%$ overseas (Andresen \& Button, 2018). This was later reinforced in interviews with senior CPS staff who alluded to domestic bribery involving relatively small amounts in terms of payments made and a wide geography of cases. Overall, domestic cases coming to the CPS were generally lower-level, 'petty' bribery cases and involve small businesses rather than larger, more complex schemes. That said, small and medium size enterprises can be more readily prosecuted and so may appear more in official data. The data received do not indicate anything about the lapse of time from offence commission to reporting/recording to investigation or to prosecution; nor about the benefits sought from the bribes, which might be larger from overseas cases, being mainly about very large contracts. The scale of the rewards sought might account for their higher average bribe size.
Only a few forces provided enough information for insights into the 'bribers', i.e. those who gave, offered or promised a bribe. More detail is given on the 'bribee', i.e. those who were offered or accepted a bribe. These included most notably bribes offered by private sector actors to those with decision-making responsibilities for awarding public contracts. Many of the Ministry of Defence Police cases involved the offering or accepting of bribes, including hospitality and gifts, for rewarding contracts to subcontractors, while there were several cases of commercial bribery, again to influence to provision of business to suppliers and subcontractors. There were also several instances of driving test examiners being bribed.

Finally, the data provided numerical information as to the outcome of the cases investigated by respondent forces-see Table 4.

The figure of 100 for 'no details on outcomes provided' is distorted by two FOI responses: Thames Valley Police (44) and Police Scotland (41). In both responses, no details were provided as to the outcomes of the offences recorded. Police Scotland does not have responsibility for charging cases, meaning outcome data was not available through the FOI request. This responsibility falls to the Crown Office and Procurator Fiscal Service (COPFS). The COPFS website contains data on all recorded offences: however, corruption is included as 'Other crimes of dishonesty', a category that includes forgery (other), 'reset' (receiving stolen goods) and embezzlement. Consequently, it is not possible to disaggregate this down to a specific focus on bribery. No further action is the most common outcome. Details provided indicated this was often due to insufficient evidence or evidential difficulties, no suspects identified or victims/ allegers withdrawing support. The outcomes 'referred elsewhere' and 'internal discipline' all related to the Ministry of Defence FOI response.

\section{Are there reasons for the divergence in terms of the domestic context?}

In summary, the paper demonstrates that bribery in the domestic context is not, numerically or in terms of the status of those investigated or decisions and actions

Table 4. Outcomes of recorded bribery cases.

\begin{tabular}{lr}
\hline No further action & 97 \\
Charge & 93 \\
Ongoing investigation /pending decision & 15 \\
Caution & 9 \\
Referred elsewhere & 4 \\
Internal discipline & 4 \\
Adult restorative disposal & 2 \\
Community resolution & 1 \\
Offence changed & 1 \\
Formal action (unspecified) & 1 \\
No details on outcomes provided & 100 \\
Total & 327 \\
\hline
\end{tabular}


involved, significant. The UK approach, whether strategic or institutional, has focused on the international context, in part because of the drivers for reform and in part because of the UK's very public commitment to taking a proactive role in addressing international bribery. There may not be significant numbers of cases in the domestic context and, unlike the transnational corporations arraigned by the SFO, few involve corporations with a high visibility or reputational significance to attract the attention of the SFO and national/international media. The third phase of the research therefore sought to explore reasons as to why there may be a divergence in responses in the domestic and international contexts.

The first explanation we found was that the levels and types of cases-or at least the levels of known cases-in the domestic context, as well as the outcomes of cases, do not create a climate of concern in themselves. The lack of centralization of information means lack of sufficient records/comparable data which indeed inhibits awareness, which may lead to the self-fulfilling prophecy that if there are not many cases or serious cases of domestic bribery (based on the data) then a different response is not necessary on the basis of the existing evidence (see also Walburg, 2015). Sometimes, low data may be a reason for concern, reflecting incompetence/corruption of the criminal justice process, but there are no clear grounds for suspicion that this is the explanation here.

Second, interviews with senior CPS staff suggested that most bribery cases that came to their attention involved 'abuse by managers', for example diverting funds, sometimes via separate companies, and bribing to maintain concealment, alongside many cases that involved using bribery to maintain subcontracts in business, as the FOI data indicated also. This level of case also does not attract official concern, even though interview data may indicate that domestic bribery reflects, as one investigator argued, a 'continuing undercurrent of corruption' (see also the Chartered Institute of Building, 2013; Fazekas, 2015) and where interviewees pointed out that official statistics on bribery and corruption do not give accurate figures. Thus the research highlights that, collectively, the known cases do not show a level of seriousness that demands official or media attention (and despite reporting on cases that, individually, included multi-million pound public sector contracts, football, the Royal Household, a $£ 4.9$ million bribe for supermarket supplies, domestic companies charged with failing to have adequate procedures, the involvement of the SFO and so on; see, for example, http://www.elexica.com/en/resources/ microsite/uk-bribery-act/corruption-enforcement-tracker). This confirms the research on media treatment of fraud, which likewise is tilted towards glamorous and 'famous name' cases (Levi, 2006).
Third, the divergence may be related to the current law enforcement approach which makes very little provision for bribery as a domestic law enforcement issue. In the case of fraud, which has been subject to review and institutional change, a lead police forcethe City of London police-is responsible for training provision through its Economic Crime Academy. There is a centralized reporting process through Action Fraud and then the dissemination of investigative packages through the National Fraud Intelligence Bureau (although there continue to be concerns over fraud investigation capacity within police forces; see, for example, Skidmore et al this issue). In the case of bribery, as the City of London Police have noted, 'as a national lead force for fraud and other economic crime, we have a degree of coordination to enable us to do that, but we do not do it for bribery and corruption ... there is no domestic sharing of intelligence on bribery' (House of Lords Bribery Act Committee, 2018, p. 4, 13). This latter issue was not helped by the recent refusal of the Home Office to fund an extension of the Action Fraud database and reporting mechanisms to include bribery. The overall perception of the priority given to the domestic bribery is a consequence of 'the focus on grand international corruption, rather than the everyday corruption that you might see in society' (House of Lords Bribery Act Committee, 2018, p. 26).

Further, prosecutorial discretion and data recording can also shape the corruption picture in the UK. For instance, many corruption cases have:

... been prosecuted with 'fraud by abuse of position' ... This enables them to think that there is no corruption going on in the UK because no one has been prosecuted for it. They've been prosecuted for something else (interview with NGO actor).

The logic of this argument implies that low absolute numbers of bribery/corruption prosecutions accounts for there being no (apparent) corruption. However, it is more likely to be a reflection on decision-making within the public authorities about when and on what charges to prosecute corruption. This might also reflect the consent needed from the Director of Public Prosecutions (DPP) for a bribery prosecution or the Attorney General (AG) for a corruption offence; such consent, from either the DPP or the AG, is not needed for prosecuting the offence of 'fraud by abuse of position', and thus the option of fraud prosecution offers a less bureaucratically complicated approach.

Fourth, there continues to be pressure from internal and external organizations that influence the enforcement priorities in terms of domestic and international bribery. For instance, the presence of intense scrutiny by inter-governmental bodies, such as the OECD's Working Group on Bribery, into how the 
UK is implementing the OECD Anti-Bribery Convention, is a major external factor (the UK government is required to communicate in person four times a year what is being done to meet the requirements of the convention). Consequently, it would be unsurprising that policy and enforcement focus has been placed on the response to international bribery which, in an ambience of resource austerity, may detract from pursuing domestic bribery:

... the attention to domestic corruption is swamped by the SFO and NCA's major focus on international corruption where they have specific mandates and where the latter's ICU [International Corruption Unit] is DFID-funded for that role (interview with law enforcement actor).

Fifth, while specific mandates and capacity have been created for national policing authorities, such as the SFO and the NCA, these are concerned with international bribery, rather than supporting local efforts against domestic bribery. This has been exacerbated by continuing funding cuts to fraud squads within local police forces who normally deal with bribery cases (see Doig, 2018). In addition, there have been wider changes in terms of domestic monitoring of the risk of bribery and appropriate institutional responses, including the abolition of both the NFA and the Audit Commission which took a leading role in monitoring levels of fraud and bribery, as well as running a national annual datamining and matching initiative, and developing comprehensive performance assessment reviews to ensure relevant policies and procedures were in place.

Finally, the nature and profile of domestic bribery may in itself attract less attention because, according to one police interviewee, it is less overt and often less tangible in comparison to the nature-and traceability - of bribery in the international context. Domestic bribery is often an extension of embedded social relation(ships) and ways of operating rather than merely specific one-off bribery transactions. The context often relates to critical 'touch points'-how and where connections are made, grooming through social and sporting occasions, shared peer groups and similar interests-as the basis for favours for friends within a shared social setting. Here there may be no bribe for specific actions but, developing from existing relationships and connectivity, a reciprocity within potentially corrupt relationships that is justifiable in terms of friendship or helping each other. Thus the bribes are less explicit tangible, material inducements than more subtle benefits (for example hospitality, employment of relatives, discounts, and so on) where there may have no direct tangible exchange, or specific payments for specified outcomes.

Taking the strands noted above together, there is a divergence in how government approaches bribery in the domestic and international contexts. This has meant that, where once domestic bribery was addressed more rigorously than bribery in the international context, this may be being steadily reversed, in terms of signalled priorities, resources and institutional responses. The paper concludes that this has come about because of a lack of governmental concern and prioritization. The consequence has also meant that, unlike the international context, the domestic context lacks institutional focus, central collation of data, resources, and appropriate training when compared to the approach to transnational bribery.

\section{What are the implications for future approaches to bribery in the domestic context?}

The lack of ownership or co-ordination of the UK approach to domestic bribery is the consequence of an absence of a collective push to build up a national profile of domestic bribery and the infrastructure that would implement the existing policy statements. This has important implications for the effective policing of bribery in the domestic context. The areas we believe need to be addressed and possible consequences if no initiative is taken to redress the divergence follow.

\section{Data on corruption}

First, our research raised several notable data issues, including the absence of a centralized register of bribery or corruption offences in the UK. This creates difficulties for determining the scale, extent and nature of domestic bribery. In previous years, the Public Sector Corruption Index (PSCl) provided a centralized register of all corruption offences. The index was set up as one of the recommendations of the 1976 Royal Commission and required all police forces to report allegations of corruption to the Metropolitan and City Police Company Fraud Branch (as it then was) which would maintain a register and would undertake a collating, evaluation and coordinating role. This Index was initially held by the Metropolitan Police before being moved to the Serious and Organised Crime Agency (SOCA, now NCA) before being allowed to lapse.

Related to this issue, as highlighted in the systematic use of FOI requests to obtain data from across UK policing agencies, is the current inconsistency of data collection and retention methods. There are no centralized expectations on how data should be stored, what data should be recorded, and for how long the data should be retained. We found that how far back data records go is dependent on individual force policies, ranging from over 20 years to 12 
months. The data that are available also vary in detail, with some forces supplying rich, contextual insight into individual cases, but others only superficial numbers, although this may reflect internal decisions over which, or how much, information to share. This is further complicated as different software and systems are being used across the different forces which, in turn, creates compatibility issues. For instance, Police Scotland gave details of 41 recorded 'corruption' offences since 2013 but, while these data include the Acts for which data was requested, we cannot be certain that they did not also include nonbribery offences. In other cases, some forces withheld some information due to sensitivities relating to potentially identifiable cases.

\section{Prosecutorial discretion}

Second, as mentioned earlier, the interviews with senior CPS actors indicated that many substantive bribery cases may be prosecuted as 'fraud by abuse of position' under the Fraud Act 2006, also reflecting police force decisions to record as fraud rather than bribery. Decisions over whether to pursue as bribery or fraud depends on several factors where the police look to expedite provable offences associated with the same criminality by considering which is 'easiest' to prove, where evidence is most readily available, and whether there is a corporate aspect to the case and which penalties can be invoked. We are not arguing that these judgments are unreasonable, but their unintended effect is to make collective assessment of harm and risk difficult.

\section{Institutional configuration and engagement}

Third is the current institutional configuration and engagement. Although the Home Office and Cabinet Office have presented a policy perspective in reducing domestic bribery, this has not been resourced or allocated in terms of institutional ownership (as opposed to guidance) and thus remains rhetorical, particularly as these bodies have a small staff with a policy or strategic rather than an operational focus. The abolition of the Audit Commission has underlined the significance of roles of, and co-ordination between, other audit or oversight bodies or regulators, where issues of awareness, prevention and reporting, especially those proposed in policy and strategy documents, may remain unmonitored or unreviewed for effective implementation.

Apart from the central role played by the City of London Police Economic Crime Academy in training police officers, and some limited guidance by the College of Policing, there is currently no central unit or resourcing for the support of local police forces for what are (by the standards of most other cases) complex, resource- and time-intensive investigations. The result may be cases not pursued because they require co-ordination, often where there may be cross-police boundaries. Within local policing, and apart from the roles of police professional standards units for police corruption and Special Operations Units (de facto regional organized crime units linked to the NCA and focused on economic crime committed by organized crime groups), strategies for the investigation of fraud, including bribery, continue to have limited effect in persuading police forces to commit appropriate resources (Doig, 2018).

\section{Political and enforcement complacency}

Finally, the absence of a major scandal or a major corporation or municipal body may have led to a 'complacency' around domestic bribery (interview with NGO actor). For instance, while the UK's role is recognized in the international side of bribery, such as in terms of the financial and professional services sectors intentionally or otherwise servicing corrupt foreigners with money laundering opportunities, or in terms of UK companies exporting bribes, bribery occurring within the UK is not part of the UK psyche (interview with NGO actor). Whether a drip-feed of domestic bribery cases can amount to enough to change the complacency and close the divergence is not clear.

\section{Conclusions}

Through our four research questions, we identified that there is a divergence in the approach to domestic and international bribery by the UK. We found that there are data, and assumptions, about the number, type and significance of cases in the domestic context that have not resulted in anything approaching the levels of responses that bribery in the international context has achieved. The response to transnational bribery has been driven not only by government commitment but also by implementing that commitment through specific institutional and resourcing changes. This has led to a divergent approach to addressing bribery in the domestic and international contexts which will have adverse implications for the prevention, detection, and investigation of bribery generally.

Operationally, levels and types of domestic bribery may be under-reported because of investigative and prosecutorial choices. More widely, we found that the interplay between national strategies and initiatives, organizational priorities, international commitments and institutional and other responses in relation to bribery remain a continuing dynamic that has favoured the international context over the domestic context. Our research may point to both a limited number of cases and low levels of complexity or 
status of those involved to explain the absence of an equivalent response in the domestic context. While there is no evidence of significant levels of bribery in the domestic context, however, the failure to respond in policy, institutional and resource terms could lead to slow reaction to any emerging rise in scale or significance in the domestic context in the future.

\section{The need for valid data on corruption}

A key issue is the reliance on enforcement data to provide insights into the nature and levels of bribery, as such data are an artefact of enforcement activities and reporting mechanisms. Alongside this, there is an absence of valid empirical data on the extent and scope of bribery offences. Social scientific methodologies utilizing self-report or victimization studies may contribute to informing this debate, but the particular nature or bribery presents obstacles: the inherently clandestine nature, the lack of identifiable victims and consequences, the invisibility of those involved in the corrupt transaction given they consent to (or otherwise incentivized to remain silent) and benefit from the arrangements, are all factors that undermine such approaches. For these reasons, we suggest more can be gained analytically by developing fuller theoretical accounts of the nature of bribery in the UK so as to inform 'intelligence-led' interventions and to pursue deliberative methods that utilize the expertise and informed judgement of key stakeholders in this area, with a view to forecasting potential future scenarios of bribery that indicate sectors, areas, issues that may emerge as priority concerns for academia, policy and practice. These offer potential future research areas.

\section{Current and future scenarios of corruption}

In the wider domestic context, unlawful paymentsoften addressed in a number of contexts, by a range of agencies under various pieces of legislation-are one of the sources that undermine the integrity of UK systems and democratic processes. Whether in business, such as the awarding of contracts in the construction sector, or public services, such as NHS staff accepting excessive hospitality to promote certain products and services, or the financing of political and election campaigns by commercial and other interests, a lack of perceived fairness can reduce legitimacy, and this permeates into society more widely. Furthermore, as we see the emergence of new sectors, such as the explosion of FinTech companies and public and private services provided via the 'internet of things', there is potential for bribery in such industries that may put at risk individual and workplace data security. In addition, the potential for using new technologies for bribery, such as utilizing anonymised cryptocurrencies as material inducements is also emerging, though very little is known about the nature of such activities.

For such reasons, in order to reduce the divergence and reinforce the domestic focus, there is a need for better and more detailed data, the presence of a single lead for the domestic context and the availability of training for relevant staff which would go a long way to anticipating such issues. In the meantime, however, the we have drawn attention to the absence of a national response and guidance to bribery in the domestic context that, given the quite substantial response for the international context, is a significant policy and strategy gap. In conclusion, governments should ensure that they have access to the appropriate levels of data to monitor the domestic context so that they may be alert to such issues in the future and address the identified divergence to enhance the implementation of the UKBA in the domestic as well as in the international contexts.

\section{Disclosure statement}

No potential conflict of interest was reported by the authors.

\section{References}

Andresen, M. S., \& Button, M. (2018). The profile and detection of bribery in Norway and England \& Wales: A comparative study. European Journal of Criminology, Online First. doi:10. $1177 / 1477370818764827$

Campbell, L., \& Lord, N. (2018). Corruption in commercial enterprise: Law, theory and practice. London: Routledge.

The Chartered Institute of Building. (2013). Report exploring corruption in the UK construction industry. London: The Chartered Institute of Building.

Doig, A. (1984). Corruption and misconduct in contemporary British politics. London: Penguin.

Doig, A. (2006). Fraud. London: Routledge.

Doig, A. (2011). State crime. London: Routledge.

Doig, A. (2018). Implementing national policing agendas and strategies for fraud at local level. Journal of Financial Crime, 25(4), 984-996.

European Commission. (2014). Report from the commission to the council and the European parliament EU anti-corruption report. Brussels: Ec.

Fazekas, M. (2015). The cost of one-party councils: Lack of electoral accountability and public procurement corruption: Report for the electoral reform society. London: Electoral Reform Society.

FCO. (2011). The Role of the FCO in UK government: Supplementary written evidence from the foreign and commonwealth office-further to the response of the secretary of state to the committee's seventh report of session 2010-12: (CM 8125). London: FCO.

GRECO. (2018). Fifth evaluation round: Preventing corruption and promoting integrity in central governments (top executive functions) and law enforcement agenciesEvaluation Report United Kingdom, GRECO.

Gutterman, E. (2017). Poverty, corruption, trade, or terrorism? Strategic framing in the politics of UK anti-bribery 
compliance. The British Journal of Politics and International Relations, 19(1), 152-171.

HM Government. (2014). UK anti-corruption plan. London: Home Office and Department for Business, Innovation and Skills.

HM Government. (2017). United Kingdom anti-corruption strategy 2017-2022. Crown Copyright.

House of Lords Bribery Act Committee. (2018). Bribery act 2010: Uncorrected oral evidence. London: House of Lords.

Law Commission. (2016). Misconduct in public office. Issues paper 1: The current law. London: Law Commission. The offence is currently subject to review by the Law Commission.

Levi, M. (2006). The media construction of financial white-collar crimes. British Journal of Criminology, 46(6), 1037-1057.

Lord, N. (2014). Regulating corporate Bribery in International Business: Anti-Corruption in the UK and Germany. Farnham: Ashgate Publishing.

OECD. (2003). United Kingdom review of implementation of the convention and 1997 recommendation phase $i$ bis report. Paris: OECD.

OECD. (2017). The detection of foreign bribery. Paris: OECD.
ONS. (2018). Statistical bulletin: Crime in England and wales: Year ending. June 2018, Retrieved from: https://www.ons. gov.uk/peoplepopulationandcommunity/crimeandjustice/ bulletins/crimeinenglandandwales/yearendingjune2018\# main-points.

Saunders, M., Lewis, P., \& Thornhill, A. (2009). Research methods for business students (Fifth edition). Harlow: Pearson Education Limited.

Transparency International. (2011). Corruption in the UK: Overview and policy recommendations. TI UK.

Transparency International. (2018). Exporting corruptionProgress report 2018: Assessing enforcement of the oecd anti-bribery convention. Berlin: TI.

UNODC. (2011). Pilot review programme: United Kingdom. review of the implementation of articles 5, 15, 16, 17, 25, 46 paragraphs 9 and 13, 52 and 53 of the United Nations convention against corruption. Vienna: UNODC.

Walburg, C. (2015). The measurement of corporate crime, an exercise in futility? In J. van Erp, W. Huisman, \& G. Vande Walle with the assistance of Becker, J. (Eds.), The routledge handbook of white-collar and corporate crime in Europe (pp. 25-38). London: Routledge. 